\section{Terbinafine and Neutropenia}

\section{Terbinafin ve Nötropeni}

To the Editor,

The article entitled "Aplastic Anemia Associated with Oral Terbinafine: A Case Report and Review of the Literature", written by Kantarcıoğlu et al. and published in a recent issue of your journal, was quite interesting [1]. Here we would like to emphasize some relevant points.

In the assessment of 425 cases by van der Klauw et al., the most common causes of drug-related agranulocytosis or neutropenia were, in order, dipyrone, mianserin, sulfasalazine, trimethoprim-sulfamethoxazole, penicillins, cimetidine, thiouracil groups, and phenylbutazone [2]. Terbinafine was not included in this list. Neutropenia associated with terbinafine is more common in women, which may be due to more fungal infections encountered and more drug usage for this purpose. To know the MCV and vitamin B12 levels in the presented patients would be useful.

In our case, a patient presented with neutropenia due to terbinafine. A 64-year-old man with a history of onychomycosis presented with neutropenia after starting terbinafine at $250 \mathrm{mg} /$ day [3]. In conclusion, routine hematological monitoring is not indicated, but patients should be informed of this potentially life-threatening adverse reaction.

\section{Conflict of Interest Statement}

The author of this paper has no conflict of interest, including specific financial interests, relationships, and/ or affiliations relevant to the subject matter or materials included in this manuscript.

Key Words: Terbinafine, Drug, Neutropenia

Anahtar Sözcükler: Terbinafin, İlaç, Nötropeni

\section{İrfan Yavaşoğlu}

Adnan Menderes University Faculty of Medicine, Division of Hematology, Aydin, Turkey

\section{References}

1. Kantarcıŏlu B, Türköz HK, Yılmaz G, Tanrıkulu FP, Atagündüz IK, Adıgüzel C, Tuğlular TF. Aplastic anemia associated with oral terbinafine: a case report and review of the literature. Turk J Hematol 2014;31:411-416.

2. van der Klauw MM, Wilson JH, Stricker BHC. Drug-associated agranulocytosis: 20 years of reporting in The Netherlands (1974-1994). Am J Hematol 1998;57:206-211.

3. Yavaşoğlu İ, Arslan E. Neutropenia due to terbinafine. Osmangazi Tip Dergisi 2008;30:59-62.
Address for Correspondence: İrfan YAVAŞOĞLU, M.D.,

Adnan Menderes University Faculty of Medicine, Division of Hematology, Aydın, Turkey

Phone:+90-256-2120020 E-mail: dryavas@hotmail.com

Received/Geliş tarihi: December 18, 2014

Accepted/Kabul tarihi: December 23, 2014

DOI: $10.4274 /$ tjh. 2014.0486

\section{Reply:}

We are very pleased by the interesting comment and participation by Yavaşoğlu. As we already mentioned in the article oral terbinafine is a highly effective agent, which is generally well tolerated. Two large-scale postmarketing surveillance studies showed that the incidence of serious side effects was $<1 \%[1,2]$. We want to clarify that the main purpose of our report was to share the experience of handling such a difficult case with colleagues who are practicing medicine, since the definite causality of aplastic anemia with oral terbinafine cannot be established [3]. The well prepared case presented by Yavaşoğlu and Arslan is another example in this regard [4]. In addition MCV and serum vitamin B12 levels were missing in most of the cases reported in the literature, but they were both in normal ranges in our case.

Bülent Kantarcıoğlu

\section{References}

1. Hall M, Monka C, Krupp P, O'Sullivan D. Safety of oral terbinafine: results of a postmarketing surveillance study in 25,884 patients. Arch Dermatol 1997;133:1213-1219.

2. O'Sullivan DP, Needham CA, Bangs A, Atkin K, Kendall FD. Postmarketing surveillance of oral terbinafine in the UK: report of a large cohort study. Br J Clin Pharmacol 1996;42:559-565.

3. Kantarcıoğlu B, Türköz HK, Yılmaz G, Tanrıkulu FP, Atagündüz IK, Adigüzel C, Tuğlular TF. Aplastic anemia associated with oral terbinafine: a case report and review of the literature. Turk J Hematol 2014;31:411-416.

4. Yavaşoğlu İ, Arslan E. Neutropenia due to terbinafine. Osmangazi Tip Dergisi 2008;30:59-62.

\section{Multiple Myeloma and Alkaline Phosphatase}

\section{Multipl Myelom ve Alkalen Fosfataz}

\section{To the Editor,}

The article entitled "Bone-Specific Alkaline Phosphatase Levels among Patients with Multiple Myeloma Receiving Various Therapy Options", written by Çetin et al. [1] and published in a recent issue of your journal, was quite interesting. Here we would like to emphasize some relevant points. 
This study was not homogeneous. It is important that the initial value of total alkaline phosphatase (ALP) be measured. In addition, in that study, had serum intact parathyroid hormone level, vitamin D level, or bone turnover markers been available, they would have provided further biochemical correlates of skeletal metabolism.

Bone-specific ALP may increase in Paget's disease, osteosarcoma, bone metastases of prostatic cancer (high/very high ALP values), other bone metastases, fractured bones, multiple myeloma (only when associated with fractures), osteomalacia, rickets, vitamin D deficiency (moderate rise), malignant tumors (ALP originating from tumors), renal disease (secondary hyperparathyroidism), and primary hypothyroidism [2,3].

Vitamin D deficiency is extremely common in multiple myeloma, with $40 \%$ of patients having vitamin D levels in the deficient range of levels less than $36 \mathrm{nmol} / \mathrm{L}$, and it represents a surrogate for clinical multiple myeloma disease status [4].

Vitamin D deficiency can cause osteomalacia and those patients can develop generalized musculoskeletal pain, proximal muscle weakness, and increased risk of falls. This may not be clinically detectable but is nonetheless present and often unrecognized [5].

\section{Conflict of Interest Statement}

The authors of this paper have no conflict of interest, including specific financial interests, relationships, and/ or affiliations relevant to the subject matter or materials included in this manuscript.

Key Words: Alkaline phosphatase, Myeloma, Vitamin D deficiency

Anahtar Sözcükler: Alkalen fosfataz, Myelom, D vitamini eksikliği

İrfan Yavaşoğlu, Gürhan Kadıköylü, Zahit Bolaman

Adnan Menderes University Faculty of Medicine, Division of Hematology,

Aydin, Turkey

\section{References}

1. Çetin G, Eşkazan AE, Ar MC, Aydın ŞÖ, Ferhanoğlu B, Soysal T, Başlar Z, Aydın Y. Bone-specific alkaline phosphatase levels among patients with multiple myeloma receiving various therapy options. Turk J Hematol 2014;31:374-380.

2. Li-Fern $H$, Rajasoorya $C$. The elevated serum alkaline phosphatase--the chase that led to two endocrinopathies and one possible unifying diagnosis. Eur J Endocrinol 1999;140:143-147.

3. Gennari L, Di Stefano M, Merlotti D, Giordano N, Martini G, Tamone C, Zatteri R, De Lucchi R, Baldi C, Vattimo A, Capoccia S, Burroni L, Geraci S, De Paola V, Calabrò A, Avanzati A, Isaia G, Nuti R. Prevalence of Paget's disease of bone in Italy. J Bone Miner Res 2005;20:1845-1850.

4. Badros A, Goloubeva O, Terpos E, Milliron T, Baer MR, Streeten E. Prevalence and significance of vitamin D deficiency in multiple myeloma patients. Br J Haematol 2008;142:492-494.

5. Diamond T, Golombick T, Manoharan A. Vitamin D status may affect the skeletal complications of multiple myeloma. Am J Hematol 2010;85:302-303.

Address for Correspondence: İrfan YAVAŞOĞLU, M.D.,

Adnan Menderes University Faculty of Medicine, Division of Hematology, Aydın, Turkey Phone: +90-256-2120020 E-mail: dryavas@hotmail.com

Received/Geliş tarihi: December 23, 2014

Accepted/Kabul tarihi: December 26, 2014

DOI: $10.4274 /$ tjh.2014.0495

Reply:

At the beginning of the study we had planned to use some other parameters with a standard multiple myeloma workup. We consulted with biostatisticians. As we compared a wide variety of patient groups in this analysis, according to the biostatisticians adding new parameters to our data would complicate the study. Therefore, we had to exclude some parameters.

We thank the reviewers for their valuable comments. We agree to plan further studies with new therapy options in small patient groups adding serum intact parathyroid hormone level, vitamin D level, and bone turnover.

\section{Güven Çetin}

